\title{
Multilateral Investment Court - a Cure for Investor-State Disputes Under Extra-EU International Investment Agreements?
}

\author{
Agata Zwolankiewicz* \\ DOI: 10.21827/GroJIL.9.1.195-211
}

\begin{abstract}
Keywords: MULTILATERAL INVESTMENT COURT; WTO; INTERNATIONAL INVESTMENT LAW; ISDS; INVESTMENT DISPUTES
\end{abstract}

\begin{abstract}
Both branches of international economic law - international investment and trade law are currently in crisis. Many reforms have been proposed to cure the shortcomings of their dispute resolution mechanisms. Distinctive though they are, it seems that the newest EU's proposal to establish the Multilateral Investment Court is heavily inspired by the dispute settlement system which exists in the World Trade Organization. The new system has been introduced to replace the investor-State dispute settlement mechanism existing in most investment treaties. In this article, the author assesses the objectives of the reform through the prism of successes and failures of the WTO dispute settlement system.
\end{abstract}

\section{Introduction}

Two major branches of international economic law - international trade and investment law have been portrayed in legal writing as Lottie and Lisa ${ }^{1}$ - identical twins separated at a very young age who reunited years later at summer camp, thanks to recognizing their identical features and heritage. For years, international trade and investment law have been regulated separately. Nonetheless, the growing interdependency between the two calls for "consolidation of the two fields, similar to reunion of Lottie and Lisa and their parents". It could be said with certainty that the dispute resolution systems under both fields, enormously different though they are, find themselves to be in crisis.

The World Trade Organization's ("WTO") dispute settlement system has been "killed from the inside". ${ }^{3}$ That is because the United States of America ("USA") has been consistently blocking new appointments to the Appellate Body which ultimately resulted in it being inoperable. At the same time, there has been significant "backlash" against the investor-State dispute settlement system ("ISDS") existing under investment treaties."

* Graduated from the University of Silesia (MA), and the University of Ottawa (LL.M. with Concentration in International Trade and Foreign Investment); azwo1094@uottawa.ca.

1 Tomer Broude, 'Investment and Trade: The 'Lottie and Lisa' of International Economic Law?' (2011) Hebrew University of Jerusalem Legal Studies Research Paper 10-11 in Pierre Sauvé and Roberto Echandi (eds) New Directions and Emerging Challenges in International Investment Law and Policy (Cambridge University Press 2012).

2 ibid 140.

3 Eduardo Porter, 'Trump's Trade Endgame Could Be the Undoing of Global Rules', (The New York Times, 31 October 2017) <https://www.nytimes.com/2017/10/31/business/economy/trump-trade.html> accessed 30 May 2021.

4 Cecilia Malmström - the EU Commissioner for Trade - dubbed ISDS mechanism as 'the most toxic acronym in Europe' see Paul Ames, "ISDS: The most toxic acronym in Europe' (Politico, 17 September 2015) < https://www.politico.eu/article/isds-the-most-toxic-acronym-in-europe/> accessed on 30 May 2021.

This work is licensed under the Creative Commons Attribution-NonCommercial-NoDerivatives 4.0 International License. To view a copy of this license, visit http://creativecommons.org/licenses/by-nc-nd/4.0/. 
Some States have opted out of it (e.g. India ${ }^{5}$ or Venezuela $\left.{ }^{6}\right)$ or revised their existing treaties (e.g. Canada-United States-Mexico Agreement ("CUSMA") ${ }^{7}$ ). One of the proposals to tweak ISDS concerns the creation of a Multilateral Investment Court - a permanent body adjudicating investment disputes with an appellate review stage inspired by the WTO dispute settlement system. ${ }^{8}$

In theory, the new dispute settlement mechanism would constitute a step towards a coherent international investment body of jurisprudence. The court would be composed of independent and impartial judges - the leading authorities in the field of international investment law. The introduction of an institutionalised judicial system aims at achieving predictability of judgements (mostly due to establishing an appellate tribunal) and more control over the costs of the proceedings and their length ${ }^{9}$. However, given the criticism surrounding the WTO Appellate Body in recent years and the crisis of the WTO dispute settlement system, we are yet to see whether the proposal to transplant a similar structure to the investment field will prove to be successful.

In this article, the author will focus on the alleged malfunctions of ISDS and whether certain aspects of it can be improved through establishing the Multilateral Investment Court. As the proposed reform draws inspiration from the WTO dispute settlement system, it seems only appropriate to evaluate the Multilateral Investment Court through the prism of advantages and disadvantages thereof. The EU put forward a plan to radically replace ISDS with a structure inspired by a WTO dispute settlement in 2015, when it was still considered as a successful dispute settlement mechanism. ${ }^{10}$ With the benefits of the hindsight, we see that there was an (un)expected turn of events.

Does it mean that transplanting the mechanisms at WTO dispute settlement system into the Multilateral Investment Court renders the initiative doomed to failure?

\section{ISDS crisis}

Investment protection has played a major role in the international law field. The current shape of it has been somewhat a result of a balance between the economic interest of States in attracting foreign investment and investors' need to have certain legal guarantees offered. ${ }^{11}$ Unlike trade law, international investment law has not been (so far) organised

5 Alison Ross, 'India's termination of BITs to begin' (Global Arbitration Review, 22 March 2017) $<$ https://globalarbitrationreview.com/article/1138510/indias-termination-of-bits-to-begin> accessed 30 May 2021.

6 Rian Matthews and Nandakumar Ponniya, 'Withdrawal from Investment Treaties: An omen for waning investor protection in AP?' (Lexology, $12 \quad$ May 17 2017) <https://www.lexology.com/library/detail.aspx?g=4bdc087c-20f0-4729-9166-1d6de9b8d2de> accessed 30 May 2021.

7 CUSMA does not provide for a trilateral ISDS mechanism. Two parties to the treaty: United States and Mexico have agreed to maintain a bilateral ISDS mechanism for a narrow set of disciplines and sectors. ISDS mechanism does not extend to Canada. The only provided recourse for investors is State-to-State dispute settlement.

8 Multilateral Investment Court: Overview of the reform proposals and prospects <https://www.europarl.europa.eu/RegData/etudes/BRIE/2020/646147/EPRS_BRI(2020)646147_E N.pdf $>$ accessed 30 May 2021.

9 Rob Howse, 'Designing a Multilateral Investment Court: Issues and Options' (2017) 36 Yearbook of European Law 209, 215.

10 Joost Pauwelyn, 'The Rule of Law without the Rule of Lawyers: Why Investment Arbitrators Are from Mars, Trade Adjudicators from Venus' (2015) 109(4) Am J Inti L 761, 764.

11 Christoph Schreuer, 'The future of International Investment Law' in Marc Bungenberg et al (eds) International Investment Law (C.H.BECK 2015) 1904, 1905. 
around a multilateral treaty or a central international organization. ${ }^{12}$ The initial enthusiasm and the States' willingness to enter into bilateral investment treaties ("BITs") providing for ISDS dispute resolution mechanism has decreased. ${ }^{13}$ Given the number of investment disputes and the awarded damages, Argentina and some European countries started wishing that "they could get the genie back into the bottle" and escape the liabilities created by BITs. ${ }^{14}$

BITs in their current form provide investors with vast protection mechanisms. These mechanisms are believed to be one-sided as only investors can pursue their claims against the States (with rare exceptions for counterclaims). Additionally, pursuant to the available information, investors have had a significant upper hand in the proceedings - under the ISDS regime, two-thirds of the cases have been settled or lost by States. ${ }^{15}$ However, despite the initial assumptions, ISDS provisions in BITs did not contribute to a considerable increase of foreign direct investment ("FDI"). In fact, several commentators questioned whether ISDS provisions contained in BITs have any impact at all on investors' decisions to establish their presence in a certain State. ${ }^{16}$ For example, Brazil consistently ranks among top 10 FDI receiving States even though it has never actually ratified any investment treaty providing for ISDS..$^{17}$

In theory, ISDS provisions were to provide a neutral, independent and efficient dispute settlement forum which was supposed to eliminate the shortcomings of domestic litigation or diplomatic protection. ${ }^{18}$ However, ISDS is not free of its own shortcomings. The backlash against it has been growing in recent years, and the opponents started calling for a reform. ${ }^{19}$ States began to exclude ISDS from the concluded investment treaties calling into question its effectiveness. ${ }^{20}$

The ISDS crisis in the EU has two dimensions - the concerns relate to the intra-EU investment arbitration as well as the extra-EU investment arbitration. The legitimacy of BITs containing ISDS provisions within the EU has been challenged since the Lisbon Treaty entered into force in 2009. Under the Treaty in question, the power to conclude BITs was transferred to the EU itself. During the travaux préparatoires, the European Commission proposed that it should have the authority to force termination or renegotiation of existing BITs concluded between the EU Member States in cases it found that BITs were incompatible with EU law. ${ }^{21}$ The proposal did not receive much support

12 Joost Pauwelyn, 'At the Edge of Chaos?: Foreign Investment Law as a Complex Adaptive System, How It Emerged and How It Can Be Reformed' (2014) 29(2) ICSID Review 372, 378.

13 United Nations UNCTAD, 'Reforming Investment Dispute Settlement: A Stocktaking, IIA Issue Notes' (Issue 1, United Nations UNCTAD 2019) <https://unctad.org/system/files/officialdocument/diaepcbinf2019d3_en.pdf>.

14 Schreuer (n 11) 1906.

15 Frank J Garcia, 'The Case Against Third-Party Funding in Investment Arbitration' (2018) $<$ https://wwwiisdorg/itn/2018/07/30/the-case-against-third-party-funding-in-investment-arbitrationfrank-garcia/> accessed 30 May 2021.

16 Kaj Hobér, 'Does Investment Arbitration have a Future?' in in Marc Bungenberg et al (eds) International Investment Law (C.H.BECK 2015) 1873, 1874.

17 United Nations UNCTAD, 'World Investment Report 2019: Special Economic Zones' (United Nations UNCTAD 2019) <https://unctad.org/system/files/official-document/WIR2019_CH2.pdf> accessed on 30 May 2021; Geraldo Vidigal and Beatriz Stevens, 'Brazil's New Model of Dispute Settlement for Investment: Return to the Past or Alternative for the Future?' (2018) 19(3) Journal of World Investment $\&$ Trade $475,485$.

18 Stephan W Schill, 'Reforming Investor-State Dispute Settlement: A (Comparative and International) Constitutional Law Framework' (2017) 20 (3) Journal of International Economic Law 649, 650.

19 Reforming Investment Dispute Settlement: A Stocktaking, IIA Issue Notes (n 13).

20 E.g. In CUSMA, under Annex 14-D, ISDS exists between Mexico and the United States but not Canada.

${ }^{21}$ Hobér (n 16) 1874. 
and ultimately it did not prevail. The majority of the Member States shared the view that intra-EU BITs are necessary and despite certain shortcomings decided to keep them in their current shape. ${ }^{22}$ However, given the recent ruling of the Court of Justice of the European Union ("CJEU") in Achmea B.V. v. the Slovak Republic ${ }^{23}$ in which the Court found that arbitration clauses in the intra-EU BITs violate the principles of EU law, the EU Member States agreed on a plurilateral treaty to terminate the intra-EU bilateral investment treaties ${ }^{24}$. This agreement aimed at terminating approximately 130 intra-EU BITs, along with the sunset clauses. It means that as of the entry into force (29 August 2020), investors cannot bring ISDS claims based on arbitration clauses included in the terminated BITs. ${ }^{25}$ However, this agreement did not put an end to the already pending arbitral proceedings. Moreover, it remains to be seen how arbitral tribunals will react to future arbitrations under intra-EU BITs and whether they will reject jurisdictional objections. $^{26}$

This article focuses on the extra-EU investment disputes and the proposal of how to reform it. The increased criticism towards ISDS made the EU seek alternatives. Its reform is based on two pillars: first, inclusion of the Investment Court System ("ICS") provisions into the newly negotiated treaties, and second, establishing a Multilateral Investment Court in lieu of ISDS. The proposal to include ICS mechanism into the treaties was introduced whilst Trans-Atlantic Trade and Investment Partnership ("TTIP") was negotiated. Further, the proposal made its way into the treaties with Canada (the Comprehensive and Economic Trade Agreement ("CETA")) and Vietnam (the EUVietnam Free Trade Agreement). On 5 May 2015, the EU issued a Concept Paper "Investment in TTIP and beyond - the path for reform" 27 in which it included an outline of an alternative to ISDS mechanism. The EU took a step further beyond the bilateral ICS included in CETA and proposed a creation of a permanent Multilateral Investment Court "which functions more like traditional court systems, by making their appointment to serve as arbitrators permanent, to move towards assimilating their qualifications to those of national judges, and to introduce an appeal system". ${ }^{28}$

The need for a replacement of ISDS was justified by the following reasons: the current system (i) imposes limitations to the right of governments to regulate in public interest, (ii) gives the investors right to sue the governments whenever the new legislation

22 Hobér (n 16) 1874.

23 Slovak Republic vs. Achmea B.V., Judgement of the Court of Justice of the European Union (Case C284/16) (6 March 2018).

24 European Commission, 'EU Member States agree on a plurilateral treaty to terminate bilateral investment treaties' (European Commission, 5 May 2020) $<$ https://ec.europa.eu/info/publications/191024-bilateral-investment-treaties_en> accessed 30 May 2021.

25 European Commission, 'EU Member States sign an agreement for the termination of intra-EU bilateral investment treaties' (European Commission, 5 May 2020) $<$ https://ec.europa.eu/info/publications/200505-bilateral-investment-treaties-agreement_en> accessed 30 May 2021.

26 Devin Bray and Surya Kapoor, 'Agreement on the Termination of Intra-EU BITs: Sunset in Stone?' (Kluwer Arbitration Blog, 4 November 2020) $<$ http://arbitrationblog.kluwerarbitration.com/2020/11/04/agreement-on-the-termination-of-intra-eubits-sunset-in-stone/> accessed 30 May 2021. For more details concerning the issue of termination of intra-EU BITs see: Gustavo Guarín Duque, 'The Termination Agreement of Intra-EU Bilateral Investment Treaties: A Spaghetti-Bowl with Fewer Ingredients and More Questions' (2020) 37 (6) Journal of International Arbitration 797.

27 European Commission, 'Concept Paper: Investment in TTIP and beyond - the path to reform' <http://trade.ec.europa.eu/doclib/docs/2015/may/tradoc_153408.PDF> accessed 30 May 2021.

28 ibid 4. 
negatively affects their profits, (iii) protects solely the interest of investors disregarding sovereign right of States to legislate in the public interest. ${ }^{29}$ Discussions regarding possible reforms have been taking place at the Working Group III of the United Nations Commission on International Trade ("UNCITRAL"). ${ }^{30}$ Whilst introducing the EU's proposal, the EU Commissioner for Trade at that time - Cecilia Malmström stated that there is "a fundamental and widespread lack of trust" in the current ISDS mechanism ${ }^{31}$ and that ISDS constitutes "the most toxic acronym in Europe". 32

The EU's proposal aims at curing the malfunctions of the current system. Hitherto, there has been no coherent protection regime in international investment law but rather a web of bilateral and regional treaties. Therefore, the EU intends to actually create such a multilateral system. However, given the reluctance of States in the past, it may require complex political negotiations on a global scale. Nonetheless, as observed by Pauwelyn, "[t]oday's benefits of a multilateral treaty must outweigh today's cost of negotiating a multilateral treaty and replacing thousands of BITs and a variety of arbitral institutions with a world investment court".33

\section{A. Criticism}

\section{i. Inconsistency}

Inconsistency and unpredictability of the awards issued by arbitral tribunals constitutes one of the most criticized drawbacks of ISDS. Currently, as in public international law, the principle of stare decisis is not applicable, the tribunals' opinions on certain matters can, and in fact do, vary. ${ }^{34}$

This issue has been discussed at the UNCITRAL Working Group III. Pursuant to the recent developments, it has been argued that introducing a review of arbitral awards may ensure consistency and coherence in adjudication. ${ }^{35}$

Investment disputes arise from "a web of more than 3,000 investment treaties, FTAs, and other similar instruments designed to foster international trade and protect foreign investors and their investments", and not a single multilateral treaty. ${ }^{36}$ Therefore, it should come as no surprise that decisions of ad hoc tribunals differ depending on the wording of the treaty and specific facts of the case. However, the critics of the system point out that such differences arise not only with regard to the cases brought under different treaties but also almost identical cases under the same treaty. ${ }^{37}$ It has been caused by the fragmentation

29 ibid 5.

30 Council of the European Union, 'Negotiating directives for a Convention establishing a multilateral court for the settlement of investment disputes' (Council of the European Union, 20 March 2018) <http://data.consilium.europa.eu/doc/document/ST-12981-2017-ADD-1-DCL-1/en/pdf> accessed 30 May 2021.

31 Proposing an Investment Court System, <https://ec.europa.eu/commission/20142019/malmstrom/blog/proposing-investment-court-system_en> accessed 30 May 2021.

32 Ames (n 4).

33 Pauwelyn (n 12) 417.

34 Hobér (n 16) 1877.

35 United Nations General Assembly, 'Note by the Secretariat, Possible reform of investor-State dispute settlement (ISDS) Appellate and multilateral court mechanisms' (29 November 2019) UN Doc A/CN.9/WG.III/WP.185, 3.

36 Gloria M Alvarez et al., 'A Response to the Criticism against ISDS by EFILA' Journal of International Arbitration 33 (2016) 8.

37 Schill (n 18) 653. 
of the system. ${ }^{38}$ The lack of coherence creates the lack of trust among the interested actors who cannot predict the result of their dispute. Thus, the driving idea of introduction of the appeal mechanism is greater consistency of decisions.

\section{ii. Impartiality and independence}

Under the current ISDS regime, arbitrators are appointed by the parties. Given the nature of this model, concerns have been raised regarding the impartiality and independence of the adjudicators. On the one hand, it has been argued that there is a general risk that the party-appointed arbitrators will favor the party who appointed them. However, there is another concern in the investment arbitration context. Since under the investment treaties only investors can initiate claims, the arbitrators could be more prone to decide in favor of them to secure future appointments. ${ }^{39}$ The seriousness of potential lack of impartiality and independence concerns has increased in the recent years, demonstrating that there is a growing distrust in the system. ${ }^{40}$

The arbitrators adjudicating investment disputes have been labelled as "private judges" who are high-powered, elite jurists. ${ }^{41}$ In March 2015, Cecilia Malmström expressed yet another criticism of ISDS, tweeting that "[w]e want the rule of law and not the rule of lawyers". ${ }^{42}$ The rate of reappointments is high, which renders ISDS "closed and elitists". ${ }^{43}$ A desire to secure future reappointments and stay in the inner circle has allegedly created a bias in favor of the party who appointed a particular arbitrator. Additionally, the possibility of arbitrators to act as counsels in other proceedings have been flagged as a potential conflict of interest referred to as "double-hatting". ${ }^{44}$ It can create justifiable doubts as to the impartiality and independence of adjudicators and undermine the trust in the dispute settlement process.

\section{iii. Regulatory chill}

The Concept Paper highlights that disregard of the right to regulate was one of the main reasons for the need to replace the current ISDS mechanism. ISDS was criticised for taking into consideration solely the interest of investors without balancing the right of the governments to regulate in the public interest. It has presumably created the possibility to sue governments in cases where the new regulations affected profits of the investors.

To provide more balance, CETA expressly included the States' right to regulate in the provisions of the treaty. Such constitutes a novel approach in comparison to previous treaties. Previously, the treaties rarely included such an explicit reference which contributed to the evolution of an asymmetric protection regime which protects the interest of investors. ${ }^{45}$ In addition to that, this asymmetric protection regime may contribute to the so-called regulatory chill. ${ }^{46}$ It has been defined as a situation in which a state authority will

38 Anders Nilsson and Oscar Englesson, 'Inconsistent Awards in Investment Treaty Arbitration: Is an Appeals Court Needed?' (2013) 5 Journal of International Arbitration 561, 574.

39 Anthony VanDuzer, 'ISDS in CETA: Is it the Gold Standard' CD Howe Commentary 459 (2016) 4.

40 ibid.

41 Joost Pauwelyn (n 10) 763

42 Cecilia Malmström, online: <https://twitter.com/malmstromeu/status/578201842678640641> accessed 30 May 2021.

43 Pauwelyn (n 10) 777.

44 Malcolm Langford, Daniel Behn and Runar Lie, 'The Ethics and Empirics of Double Hatting' (2017) 6(7) ESIL Reflection; Henrique M Sachetim and Rafael R Codeço, 'The Investor-State Dispute Settlement System amidst Crisis, Collapse, and Reform' (2019) 6(1) The Arbitration Brief 20, 11.

45 Investment in TTIP and beyond - the path to reform (n 27) 5.

46 Julia G Brown, 'International Investment Agreements: Regulatory Chill in the Face of Litigious Heat?' (2013) 3 (1) Western Journal of Legal Studies 13; The Impact of Investor-State-Dispute Settlement (ISDS) 
refrain from enacting or enforcing regulatory measures because it fears that it would lead to investment arbitration. ${ }^{47}$

The most frequently cited cases which had implications for introducing legislative changes in other States were Philip Morris vs. Uruguay ${ }^{48}$ and Philip Morris vs. Australia ${ }^{49}$. Both cases concerned plain packaging regulations which aimed at protecting public health. Other countries put their legislation efforts concerning plain packaging on hold as they were waiting for the result of the arbitral proceedings initiated by Philip Morris. ${ }^{50}$

\section{iv. Lack of transparency}

One of the aspects that has been largely criticised is the lack of transparency. In commercial arbitration, confidentiality is usually perceived as an advantage. However, in investor-State arbitration, which largely resembles public litigation, it seems to create a lot of distrust and animosity. The New York Times criticized ISDS by stating that: "[ $t]$ heir meetings are secret. Their numbers are generally unknown. The decisions they reach need not be fully disclosed. Yet the way a small group of international tribunals handles disputes between investors and foreign governments has led to national laws being revoked, justice systems questioned, and environmental regulations challenged". ${ }^{51}$ The perception of arbitrators adjudicating disputes does not help the legitimacy of the system either. Arbitrators have been described as an homogenous group of "older white man" - an "old boys club". ${ }^{52}$ Even though efforts have been made to introduce more transparency into ISDS, e.g., through United Nation Commission on International Trade Law ("UNCITRAL") Rules on Transparency in Treaty-based Investor-State Arbitration, which came into force on 1 April 2014, ISDS still remains dubious in the public eye. As noted by the EU, the UNCITRAL regulations on transparency are insufficient since "they do not specifically provide for right to intervene to persons with a clear and concrete interest in the case". ${ }^{53}$ Thus, Working Group III at UNCITRAL advocates for a high level of transparency and enabling e.g., representatives of communities affected by the dispute to participate in investment disputes. ${ }^{54}$

Additionally, there are number of concerns concerning publication of arbitral awards. There is no uniform obligation to publish the arbitral awards. Some treaties can impose such an obligation, however it is unusual (e.g. Under Annex 1137.4 of North

in the Transatlantic Trade and Investment Partnership, <www.rijksoverheid.nl/documenten-enpublicaties/rapporten/2014/06/24/the-impact-of-investorstate-dispute-settlement-isds-in-the-ttip.html> accessed 30 May 2021, 40,

47 The Impact of Investor-State-Dispute Settlement (ISDS) in the Transatlantic Trade and Investment Partnership (n 46) 41.

48 Philip Morris vs. Uruguay, ICSID Case No. ARB/10/7.

49 Philip Morris vs. Australia, PCA Case No. 2012-12.

50 Tarald Laudal Berge and Axel Berger, 'Does investor-state dispute settlement lead to regulatory chill? Global evidence from environmental regulation' (Semantic Scholar, 2019) $<$ https://www.semanticscholar.org/paper/Does-investor-state-dispute-settlement-lead-to-from-BergeBerger/4afb08a676d0c17058db629b4134c52d28bf6942> accessed 30 May 2021.

51 Anthony Depalma, 'Nafta's Powerful Little Secret; Obscure Tribunals Settle Disputes, but Go Too Far, Critics Say' (The New York Times, 11 March 2001) $<$ https://www.nytimes.com/2001/03/11/business/nafta-s-powerful-little-secret-obscure-tribunalssettle-disputes-but-go-too-far.html> accessed 30 May 2021.

52 Sergio Puig, 'Social Capital in the Arbitration Market' (2014) 25(2) European Journal of International Law 387, 388; Leigh Swigart and Daniel Terris, 'Who are International Judges?' in Cesare PR Romano, Karen J Alter, and Yuval Shany (eds) The Oxford Handbook of International Adjudication (Oxford Handbooks 2015) 635.

53 Investment in TTIP and beyond - the path for reform (n 27$) 7$.

54 Possible reform of investor-State dispute settlement (n 35) 12. 
American Free Trade Agreement ("NAFTA"), an award may be made public by the investor or Canada or the United States if they are the disputing party). With regard to the arbitral rules, the ICSID Rules only provide that it will publish the award if there is a mutual consent of the parties. Rule 48 sets forth that: "[t] $\mathrm{the}$ Centre shall not publish the award without the consent of the parties. The Centre shall, however, promptly include in its publications excerpts of the legal reasoning of the Tribunal". Given that the investment proceedings resemble public litigation and usually involve matters of public interest, this prevailing confidentiality has been perceived as a drawback of the system.

Nonetheless, steps have been made to tackle this concern. On December 2014, a UN Convention on Transparency in Treaty-based Investor-State Arbitration was adopted, as of March 2020, it has been signed by 23 States. ${ }^{55}$ The Convention is applicable to any dispute arising under an investment treaty which came into force before 1 April 2014 (unless a State opts-out). The Convention imposes "an extensive transparency regime, including publication of substantive pleadings, final awards and other documents associated with arbitration proceedings". ${ }^{56}$ Therefore, it demonstrates that ISDS is receptive to criticism and may adapt to new challenges developed over time.

\section{WTO Dispute Settlement Crisis}

There is a prevailing view that the WTO crisis was created by Donald Trump's new approach to international trade. This view has been fuelled by information present in the media. ${ }^{57}$ However, it has been over a decade since the United States started voicing its concerns with regard to the functioning of the WTO dispute settlement system. The main concern presented by the United States has related to the functioning of the Appellate Body - the alleged failure to respect the procedural provisions by its members and progressive self-empowerment. ${ }^{58}$ The Appellate Body was established in 1995, introducing for the first time an appellate stage of proceedings in international trade law. The review stage was created to ensure that there would be a mechanism to rectify panel reports despite their automatic adoption. ${ }^{59}$ Interestingly, in the beginning, the United States supported the strengthening of the WTO dispute settlement system. ${ }^{60}$ At the end of the day, the United States' tactic resulted in its collapse - the Appellate Body does not have a sufficient number of members to hear appeals.

The United States shared more insight into its specific dissatisfaction with the regime most recently in "Report on the Appellate Body of the World Trade Organization"

55 United Nations UNCITRAL 'Status: United Nations Convention on Transparency in Treaty-based Investor-State Arbitration' (UN UNCITRAL, $<$ https://uncitral.un.org/en/texts/arbitration/conventions/transparency/status > accessed 30 May 2021.

56 Filip Balcerzak and Jarrod Hepburn, 'Publication of Investment Treaty Awards: The Qualified Potential of Domestic Access to Information Laws' (2015) 3 (1) Groningen Journal of International Law 147, 152.

57 Farah N Jan, 'Trump's War on the World Trade Organization: The international trading order is weakening as a result of U.S. actions' (The Diplomat, 12 December 2019) $<$ https://thediplomat.com/2019/12/trumps-war-on-the-world-trade-organization/> accessed 25 May 2021.

58 Elvire Fabry and Erik Tate, 'Saving the WTO Appellate Body or returning to the wild west of trade' (2018) 225 Policy Paper, 8-9.

59 Jeffrey Waincymer, WTO litigation: procedural aspects of formal dispute settlement (London: Cameron May, 2002) 693.

60 Anwarul Hoda, 'Where Is US Trade Policy Headed Under the Trump Administration?' (2019) 20 Years of G20 81, 90 .

61 Office of the US Trade Representative: Report on the Appellate Body of the World Trade Organisation $<$ https://ustr.gov/sites/default/files/Report_on_the_Appellate_Body_of_the_World_Trade_Organizat ion.pdf $>$ accessed on 30 May 2021. 
criticism inter alia concerned the disregard of the 90-day time period for deciding on appeals $^{62}$. In line with Article 17.5 Dispute Settlement Understanding ("DSU"), the proceedings should not exceed 90 days.

The Appellate Body managed to decide on appeals within the imposed time limits in the first years of its establishment. Out of 101 appeals, in 87 it respected the 90-day deadline, and in the remaining 14, the Appellate Body consulted the parties and after obtaining their consent, exceeded 90-days to review the appeal. ${ }^{63}$ However, with the time passing and the alleged self-empowerment, the Appellate Body changed its approach and infringed certain procedural regulations. In 2011, in US-Tyres ${ }^{64}$, the Appellate Body not only exceeded the 90-day limit without any explanation for the delay but also did not consult with the parties regarding exceeding the time limit prescribed by the DSU.

The USA's negative reaction went unnoticed. ${ }^{65}$ Since then, the Appellate Body has been increasing thetime needed for hearing disputes, between 2014 and 2017 achieving on average 149 days $^{66}$. As pointed out by the United States, time limits set forth in the DSU are not discretionary and the Appellate Body cannot disregard or amend them. ${ }^{67}$ Additionally, it was raised that the Appellate Body would be able to meet the time limits if it would not overstep other aspects of adjudicating disputes - unnecessarily address unimportant issues to resolve the case (obiter dicta decisions). For example, in ArgentinaFinancial Services ${ }^{68}$, the USA was alleging that more than two-thirds (46 pages) of the Appellate Body's analysis were of obiter dicta nature. Despite the main issue being the understanding of likeness requirements, the Appellate Body interpreted various unrelated provisions of GATS. ${ }^{69}$

The United States also heavily criticised participation of the Appellate Body members in the adjudication process after the expiry of their tenure. ${ }^{70}$ Authorizing a person who is no longer a member of the Appellate Body raised many concerns. Pursuant to Rule 15 in the Appellate Body's Working Procedures "a person who ceases to be a Member of the Appellate Body may, with the authorization of the Appellate Body and upon notification to the DSB, complete the disposition of any appeal to which that person was assigned while a Member [...]". The United States stated that the WTO Members never approved of such a regulation and it is of the opinion that pursuant to the view of the United States, "under the WTO Agreement, it is the Dispute Settlement Body, not the Appellate Body, that has the authority and responsibility to decide whether a person whose

62 ibid 41.

63 Statement by the United States at the Meeting of the WTO Dispute Settlement Body. Geneva, June 22, 2018 (2018) <https://geneva.usmission.gov/wp-content/uploads/sites/290/Jun22.DSB_.Stmt_.asdelivered.fin_.public.rev_.pdf> accessed on 30 May 2021.

64 United States - Measures Affecting Imports of Certain Passenger Vehicle and Light Truck Tyres from China, WT/DS399/AB/R, 5 September 2011.

65 Minutes of the DSB Meeting on October 5, 2011 (WT/DSB/B/304) at 4.

66 Office of the US Trade Representative: Report on the Appellate Body of the World Trade Organisation (n 61) at 30.

67 Statement by the United States of 22 June 2018 (n 63).

68 Argentina - Measures Relating to Trade in Goods and Services, WT/DS453/AB/R, 14 April 2016.

69 Statement by the United States at the Meeting of the WTO Dispute Settlement Body of 23 May $2016<$ https://www.wto.org/english/news_e/news16_e/us_statment_dsbmay16_e.pdf.> accessed 30 May 2021.

70 Statement by the United States at the Meeting of the WTO Dispute Settlement Body. Geneva, February 28, 2018 (2018) <https://geneva.usmission.gov/2018/03/01/statements-by-the-united-states-at-thefebruary-28-2018-dsb-meeting/> accessed 30 May 2021. 
term of appointment has expired should continue serving". ${ }^{71}$ Moreover, even though the Appellate Body can issue their own working procedures, it cannot "disregard or modify the DSU [...], and that is what Rule 15 purports to do". ${ }^{72}$

Lastly, the United States criticized the Appellate Body for making factual findings. Under Art. 17.6 DSU, an appeal is limited to the issues of law in the panel report. The Appellate Body cannot make new factual findings ${ }^{73}$ as such task was assigned to panels. However, in case the panel report is not sufficiently exhaustive, the Appellate Body is unable to decide on an appeal. ${ }^{74}$ The Appellate Body does not have the power to remand the case back to the panel for further fact-finding. The lack of such powers was dubbed in legal writing as a "design flaw" of the WTO system. ${ }^{75}$ That has led to the Appellate Body crossing the "procedural" lines and engaging in fact finding at the appellate stage. Again, the United States contends that the Appellate Body has increased the violation of the review standard with time. ${ }^{76}$ In its view, it "harmed the dispute settlement system" since "invention of such authority has added complexity, duplication, and delay to WTO disputes". ${ }^{77}$

\section{Multilateral Investment Court}

The criticism towards the investor-State dispute settlement prompted debates over alternatives to investment arbitration. The EU came up with an alternative judicialised system of settling investment disputes, following the findings of its online consultation with respect to investor protection in TTIP. The European Parliament concluded that investment disputes should rather be settled by a standing judicial body and not by ad hoc panels in arbitral proceedings. ${ }^{78}$ In September 2015, the EU initially proposed inclusion of bilateral investment court system whilst negotiating the new international investment treaties -TTIP as well as CETA. The bilateral system would eventually be replaced by a Multilateral Investment Court to settle investment disputes in lieu of investor-State arbitration.

The main reasons for seeking a change and introducing an institutionalised judicial system is the predictability of judgements, independence and impartiality of judges, appellate stage and more control over the costs of the proceedings and their length. ${ }^{79}$ Additionally, since 2017, the UNCITRAL Working Group III has been discussing potential options for amending ISDS. The Working Group III resumed its works in January 2020. During the meeting, issues arising out of the creation of a multilateral investment court have been discussed, especially concerning its jurisdiction, relations to other legal norms and institutions, the appellate mechanism and appointment of adjudicators. There are still numerous questions left for consideration, pertaining mostly to the structural and enforcement issues. The current negotiations on establishing an investment court, and in a further stage a Multilateral Investment Court, however, do not

71 Office of the US Trade Representative: Report on the Appellate Body of the World Trade Organisation (n 61) 33.

72 ibid 34

73 See Art 17.6 DSU: 'An appeal shall be limited to issues of law covered in the panel report and legal interpretations developed by the panel'.

74 Waincymer (n 59) 372.

75 Joost Pauwelyn, Appeal without remand: a design flaw in WTO dispute settlement and how to fix it (Geneva: ICTSD International Centre for Trade and Sustainable Development, 2007).

76 Office of the US Trade Representative: Report on the Appellate Body of the World Trade Organisation (n 61) 39.

77 ibid 44.

78 Howse (n 9) 211.

79 ibid 215. 
address the substantive investment standards. ${ }^{80}$ Therefore, currently, the discussion is mainly focused on addressing the change of structural aspects of the hitherto ISDS as we know it but the treaty imbalance creating asymmetrical protection regime (such as the possibility of counterclaims) has been neglected so far.

The ISDS reform is difficult given the number of IIAs already in place. The initial proposal of a bilateral system in CETA seems to be insufficient on a bigger scale. Therefore, establishing a truly multilateral investment court could aide in achieving a long-term goal. ${ }^{81}$

\section{A. Structure of Multilateral Investment Court}

The Multilateral Investment Court would form an independent investment organization composed of its own internal bodies. It would operate on the basis of a treaty, with its separate legal personality. ${ }^{82}$ In this analysis, the current proposals of a dispute settlement included in CETA will be used as a starting point of analysis of the prospective Multilateral Investment Court. It should be composed of a general plenary body making all the important decisions concerning its operation. As indicated in legal doctrine, plenary bodies are an essential part of every international organization. They are generally composed of representatives of member states and can be further divided into committees and subcommittees dealing with different issues. ${ }^{83}$ The plenary body would hold periodical meetings with the possibility of conducting extraordinary sessions if there is a need. ${ }^{84}$ The tasks of the plenary body would include appointment of the judges, adoption of procedural rules and annual budget.

With regard to adjudicators, it has been advocated that the number of appointed judges should be limited. ${ }^{85}$ Moreover, it was advised that it should not be based on the number of members but rather on the caseload, which naturally will be dependent on the number of participating States. ${ }^{86}$ Additionally, it would be desirable if the composition of the Multilateral Investment Court reflected diversity of various legal systems as well as geographical and cultural regions. ${ }^{87}$ Such could be achieved by appointment of a designated number of judges from different regional groups (such us African, Asian, Eastern European, Western European, Latin American and Caribbean, South American and North American). ${ }^{88}$ Lack of formation of regional groups could result in placing nationals of politically strong countries by which developing countries could potentially be excluded from being equally represented. ${ }^{89}$ Members will sit in division of three. CETA also sets forth that the members of the tribunal should be appointed for a 5 -year term, renewable once.

Art. 8.28 CETA introduces the Appellate Tribunal which will review awards rendered by the first-instance Tribunal. The awards may be upheld, modified or reversed

80 Rhea T Hoffmann, 'The Multilateral Investment Court: A Stumbling Block for Comprehensive and Sustainable Investment Law Reform' (2018) SSRN Electronic Journal, 4.

81 Makane M Mbengue and Stefanie Schacherer, Foreign investment under the comprehensive economic and trade agreement (CETA) (Cham, Switzerland: Springer, 2019) 202.

82 Marc Bungenberg and August Reinisch, From bilateral arbitral tribunals and investment courts to a multilateral investment court: options regarding the institutionalization of investor-state dispute settlement (Berlin, Germany: Springer Open, 2018) 2.

83 Bungenberg and Reinisch (n 82) 27-28.

84 ibid 28.

85 ibid 29.

86 ibid 29.

87 In CETA, under Article 8.27, a proposal was made to appoint 15 members of the Tribunal in equal numbers from Canada (5), the EU (5), and nationals from other countries (5).

88 Geographical representation was adopted by e.g. the International Tribunal for the Law of the Sea.

89 Bungenberg and Reinisch (n 82) 34. 
based on inter alia errors in the application or interpretation of law and manifest errors in the appreciation of the facts.

International organizations also have administrative bodies which help with the dispute settlement process. The proposed secretariat at the Multilateral Investment Court could not only administer the pending cases but also provide linguistic and translation services. Additionally, the staff at the secretariat could assist the judges with legal research and preparation of their decisions. ${ }^{90}$

This proposal largely resembles the structure of the Appellate Body at the WTO, however, contrary to the WTO dispute settlement system, it also introduces a standing Tribunal of the first instance.

\section{B. Outcomes}

Despite extreme changes with regard to the structure of investment dispute resolution and creation of a standing Multilateral Investment Court, so far, the EU's proposal has not tackled the core of ISDS shortcomings. The current debate focuses on institutional issues such as qualification and selection of judges, appellate mechanism, etc. However, the mandate of the Commission to negotiate the creation of a Multilateral Investment Court is limited. It does not include substantive protection of investment agreements such as imposing obligations to protect human rights and the environment. The substantive obligations are subject to negotiations with regard to each new IIA. However, there will be no single multilateral instrument which would provide some substantive "ground rules". The reform does not cover certain procedural aspects such as the advocated possibility of submitting counterclaims by the States. The current negotiations do not address the issue of locus standi in a dispute. ${ }^{91}$ Public Service International ("PSI"; a global trade union federation advocating for human rights and social justice) accused the proposal of being "the EU's latest corporate privilege rebrand". ${ }^{92}$

In the following, the author will focus on several of the aspects of the reform which supposedly aim at improving the current system.

\section{i. Predictability}

The replacement of ad hoc arbitral proceedings within the ISDS framework by the Multilateral Investment Court aims at eliminating unpredictability and inconsistency of arbitral awards one of the main disadvantages of ISDS. The main criticism is that ISDS has produced different awards in cases involving similar facts and law. ${ }^{93}$

On the opposite side, there is WTO. The WTO dispute settlement constitutes an example of a system in which deciding on disputes by appointed judges instead of ad hoc arbitral tribunals allowed to establish a stable and consistent jurisprudence. ${ }^{94}$ Such result could also be achieved due to the existence of the Appellate Body which facilitated elimination of divergent panel reports.

In that case, a Multilateral Investment Court with an appellate stage would provide a great harmonizing effect. A uniform approach to legal issues would contribute to a coherent body of jurisprudence even if the disputes arise out of violations of different IIAs.

90 ibid 55.

91 Hoffmann (n 80) 8.

92 Public Services International, 'The Multilateral Investment Court: the wolf's newest outfit' (Public Services International) <http://www.world-psi.org/sites/default/files/mic_fact_sheet2.pdf $>$ accessed 30 May 2021.

93 Lee M Caplan, 'ISDS Reform and the Proposal for a Multilateral Investment Court' (2019) 46 (1) Ecology LQ 53, 57.

94 Howse (n 9) 2015. 
It would be achieved through appellate proceedings involving permanently appointed arbitrators. ${ }^{95}$ The appellate stage is meant to eliminate divergent decisions and provide consistency in the field of international investment law. ${ }^{96}$ At the end of the day, ensuring greater consistency would have a positive impact on acceptance of the rendered arbitral awards and an overall legitimacy of the system. ${ }^{97}$ Additionally, greater consistency and predictability may have a positive impact on the States' awareness regarding their regulatory boundaries. ${ }^{98}$

However, consistency and predictability of the awards should not constitute an ultimate goal and should not be achieved at all costs. Indeed, introduction of the Multilateral Investment Court may increase stability and legitimacy of the system, however, it comes at a price: a decrease in accuracy, sincerity and transparency. ${ }^{99}$ Consistency does not by any means guarantee accuracy of arbitral awards - as one may be consistently wrong. Introduction of the Multilateral Investment Court with an appellate mechanism may not allow for much needed flexibility either. The lack of such features of adjudication was actually one of the reasons why the USA blocked the new appointments to the Appellate Body. Despite the lack of formal doctrine of stare decisis, the previous decisions of the Appellate Body were of tremendous importance at the WTO and panels could not have freely disregarded legal interpretations in reports adopted by the Dispute Settlement Body. ${ }^{100}$ The United States argued that treating interpretation in one dispute as a binding precedent or an authoritative interpretation of the covered agreement contradicted the provisions of the WTO Agreement. ${ }^{101}$

Binding precedents do not increase the legitimacy of the dispute settlement system. It was advocated that actually providing the reasoning and motives of a decision is more convincing than simply relying on past decisions. ${ }^{102}$ Attempts to achieve predictability of the system at all costs by the proposed reform may turn out to be more detrimental to resolution of investment disputes than the current mechanism. That is because, in the last years the cross-references between the arbitral awards in investment arbitration have increased (despite the lack of formal stare decisis doctrine in investment arbitration). Such practices and further evolution of jurisprudence in investment disputes could naturally lead to more predictability and stability of the system. ${ }^{103}$

\section{ii. Supporting staff}

One of the advantages of creating a Multilateral Investment Court which received little attention from legal commentators is the permanent supporting staff. The support may range from tasks such as assisting the judges in legal research, translation of documents to

95 Hobér (n 16) 1877.

96 Jonathan J Saulino and Josh Kallmer, 'The Emperor Has No Clothes: A Critique of the Debate Over Reform of the ISDS System' in Jean E Kalicki and Anna Joubin-Bret (eds) Reshaping the Investor-State Dispute Settlement System (Brill NV 2015) 519.

97 Bungenberg and Reinisch (n 82) 2.

98 Sachetim and Codeço (n 44) 19.

99 Irene M Ten Cate, 'The Costs of Consistency: Precedent in Investment Treaty Arbitration' (2013) 51 Columbia Journal of Transnational law 418, 420.

100 Anne Scully-Hill and Hans Mahncke, 'The Emergence of the Doctrine of Stare Decisis in the World Trade Organization Dispute Settlement System' (2009) 36 (2) Legal Issues of Economic Integration 133, 143.

101 Office of the US Trade Representative: Report on the Appellate Body of the World Trade Organisation (n 61) at 56.

102 Ten Cate (n 99) 461.

${ }^{103}$ Pauwelyn (n 12). 
organizing case files and overall administration of the disputes. ${ }^{104}$ Such supporting staff does not constitute a novelty - legal scholars note that a considerable number of international courts and dispute resolution organizations has administrative support. ${ }^{105}$ Such staff could significantly improve the handling of caseload and also ensure that the staff is properly qualified and trained for the tasks. The existence of administrative support, in theory, has been found to positively influence not only efficiency of the court but also independence and impartiality of adjudicators. ${ }^{106}$

Creating a permanent support-staff body similar to the WTO structure also has its downsides. It can ultimately cause more harm than expected if not conducted properly. The USA's criticism towards the WTO was not only directed at the Appellate Body members but also at the overreaching power of the Secretariat. The Secretariat's role goes far beyond simple administrative help for adjudicators - they conduct legal research, participate in all closed-proceedings and even draft the questions that adjudicators ask of the parties. ${ }^{107}$ In the study conducted by Pauwelyn and Pelc, the analysis demonstrated that it was actually the support staff at the Secretariat who drafted a significant number of panel rulings - and thus creating the de facto precedent in the international trade law. ${ }^{108}$

Therefore, there is also a risk concerning such a secretariat existing in the Multilateral Investment Court framework. The permanent supporting staff could play a major role in the adjudicating process and set the tone for future arbitral awards.

\section{iii. Appellate proceedings}

CETA includes a proposal to introduce an appellate stage of proceedings. The treaty provides for "the establishment of a multilateral investment tribunal and appellate mechanism". ${ }^{109}$ The main reason for the two-tier proceedings is to ensure that "the appellate body would create a body of decisions to provide helpful precedents and consistency". ${ }^{110}$ The appellate body, similar to the WTO Appellate Body would review errors of law. ${ }^{111}$ On the one hand, appeal proceedings contradict the finality of the arbitral awards. On the other hand, it has been argued that an appellate stage will improve the quality and consistency of arbitral awards. ${ }^{112}$ An appellate stage would introduce a corrective mechanism but also the court of first instance would be encouraged to produce a clear, consistent and coherent judgement to previous similar cases. In its proposal, the

104 Eduardo Zuleta, 'The Challenges of Creating a Standing International Investment Court' in Jean E Kalicki and Anna Joubin-Bret (eds) Reshaping the Investor-State Dispute Settlement System (Brill NV 2015) 403, 417.

105 Bungenberg and Reinisch (n 82) 55.

106 Céline Lévesque, 'The European Commission Proposal for an Investment Court System:' Investor-State Arbitration Series 59, 98.

107 Krzysztof J Pelc and Joost Pauwelyn, 'The WTO's trade dispute appeal system could end on Dec. 10. Here's what you need to know" (The Washington Post, 12 May 2019) <https://www.washingtonpost.com/politics/2019/12/05/wtos-trade-dispute-appeal-system-couldend-dec-heres-what-you-need-know/> accessed 30 May 2021.

108 Joost Pauwelyn and Krzysztof Pelc, 'Who Writes the Rulings of the World Trade Organization? A Critical Assessment of the Role of the Secretariat in WTO Dispute Settlement' (2019) SSRN Electronic Journal.

109 Article 8.29 CETA: "The Parties shall pursue with other trading partners the establishment of a multilateral investment tribunal and appellate mechanism for the resolution of investment disputes. Upon establishment of such a multilateral mechanism, the CETA Joint Committee shall adopt a decision providing that investment disputes under this Section will be decided pursuant to the multilateral mechanism and make appropriate transitional arrangements".

${ }^{110}$ Luis González García, 'Making Impossible Investor-State Reform Possible' in Jean E Kalicki and Anna Joubin-Bret (eds) Reshaping the Investor-State Dispute Settlement System (Brill NV 2015) 424, 430.

111 Howse (n 9) 233.

112 Mbengue and Schacherer (n 81) 263. 
EU stated that time limits should be introduced in order to ensure that the appellate mechanism does not result in delays in the proceedings. ${ }^{113}$

The downside is that the introduction of the appellate stage of the proceedings may significantly prolong the adjudicating process. Despite the time limits to decide on the appeals, one needs to look no further than to the WTO Appellate Body. In its beginnings, it was predicted that only a fraction of panel reports would be appealed. ${ }^{114}$ The reality turned out to be quite different. As of 2007, 70 percent of cases were appealed ${ }^{115}$. This number has been increasing and in 2016 amounted to nearly $90 \%{ }^{116}$.

There is a risk that with the (potentially) increasing investment deputes, an appellate stage of proceedings will significantly prolong the dispute resolution process. That might be the case depending on the number of the appeals.

\section{iv. Independence and impartiality of adjudicators}

The proposal to establish a permanent court with appointed arbitrators also aims atproviding a greater trust in the process through ensuring independence and impartiality of the judges. In CETA, pursuant to Article 8.27, the judges hold permanent appointments and "thus cannot wear a double hat". ${ }^{117}$ A concern has been expressed that currently arbitrators can simultaneously serve as arbitrators and counsels to clients - wear a double hat - which resulted in a decrease of public trust. ${ }^{118}$ Having a standing court with appointed judges would allow to eliminate the current risk of conflicts of interest of arbitrators. It has been advocated that judges of a permanent court would provide longer tenures and ultimately result in greater independency and impartiality of adjudicators ad hoc arbitrators who have an interest in securing future appointments. ${ }^{119}$ Thus, arbitrators could be tempted to adjudicate in the interest of the party who appointed them.

Following a regional appointment model proposed by legal scholars would also ensure even cultural representation.

On the other hand, however, the proposed system of appointment of the arbitrators may create more imbalance. Under the current system, the arbitrators are appointed by the parties, which gives them an equal power to make a decision on the composition of the arbitral tribunal. In line with the proposed reform, arbitrators would be solely appointed by the States. There is a risk that such one-sided appointments would weaken the idea of a truly party-neutral arbitral tribunal. ${ }^{120}$ A risk that was mentioned in legal writing was that only "pro-state" individuals would be chosen. It could lead to tilting the system in favor of the States. That could also be a result of the profile of the chosen arbitrators. The States may be unintentionally prone to selecting arbitrators with more experience in governmental and diplomatic positions than in private sector. That is even more so, since CETA introduces a vital change in the appointment system. So far, one of the main challenges to ISDS concerned the "double-hat" practice, allowing the arbitrator to act as a counsel in other proceedings. Under Art. 8.30 CETA, the arbitrators "shall refrain from acting as counsel or as party-appointed expert or witness in any pending or new investment dispute under this or any other international agreement". It means that the system itself,

113 Investment in TTIP and beyond - the path to reform (n 27) 8.

114 Peter van der Bossche, The law and policy of the World Trade Organization (CUP 2008) 288.

115 Bossche (n 114) 288.

116 Fabry and Tate (n 58) 294.

117 Howse (n 9) 213.

118 Zuleta (n 104) 411.

119 Lee M Caplan (n 93) 58.

120 Sonja Heppner, 'A critical appraisal of the investment court system proposed by the European Commission’ 72(2) Dispute Resolution Journal (2017) 108. 
would favor appointment of academics, former government officials and former judges. It is therefore highly unlikely that practicing lawyers will be interested in the position and even if, those would only be "established players" who can afford to act only as arbitrators. ${ }^{121}$

The party-appointment system has been considered to enhance investors trust in ISDS. ${ }^{122}$ Thus, the abrupt change may result in the lack of legitimacy of the Multilateral Investment Court. Moreover, it is not exactly clear what constitutes the alleged judicial bias which the EU is attempting to eliminate. ISDS already provides for procedural safeguards which ensure that cases are not heard by the arbitrators who are not impartial and independent. Similarly, the International Bar Association ("IBA") Guidelines on Conflicts of Interest in International Arbitration serve a similar role.

Thus, eliminating the party-appointed arbitrators and introducing a one-sided system of such appointments could result in a less-balanced dispute resolution.

\section{Assessment: "structural rebranding"?}

The Multilateral Investment Court is perceived by some as a "re-branding exercise" since a court system "does not alter the fundamental problems within". ${ }^{23}$ As indicated in legal writing, a mere replacement of "arbitrators with judges" without making changes to the standards of investment protection in the treaties themselves resembles more a placebo effect than a true transformation of the regime- instead of a reform of substantive norms, amendments to dispute resolution constitute only a touch-up and do not solve the core of the issue. ${ }^{124}$ One must take a step back and ponder about the shortcomings of ISDS that the reform aims at resolving - the issue with ISDS was not so much the format of the dispute settlement itself but the substantive obligations undertaken by the States under IIAs.

In the sections above, the author has expressed doubts whether the potential advantages are not in fact the shortcomings of the proposed reform in disguise. History teaches us based on the experience with the downfall of the Appellate Body that such dispute settlement mechanisms may not necessarily work well in practice.

The Multilateral Investment Court was criticized for being "a poor alternative" to ISDS because it "has the combined flaws of the General Agreement on Tariffs and Trade (GATT) before the World Trade Organization (WTO) was founded, the current WTO appellate body, and the maligned ISDS systems all in the basic plan". ${ }^{125}$ International investment law - as it currently stands - is decentralized and adapts with time to changing circumstances. It has emerged organically as there was no major constitutional moment up until recently. ${ }^{126}$ Changing the current state of play and introducing centralization, may turn out to be in fact detrimental as "FIL [Foreign Investment Law] and its self-organizing qualities demonstrate that high levels of centralization and global control are not indispensable for a regime to thrive" ${ }^{127}$. For example, the increasing cross-references in

\footnotetext{
121 Lévesque (n 106).

122 Sachetim and Codeço (n 44) 25.

123 The Greens in the European Parliament, 'Multilateral Investment Court, Press Release' (The Greens/EFA, 20 March 2018) <https://www.greens-efa.eu/en/article/press/multilateral-investment-court-littlemore-than-a-rebranding-exercise $>$ accessed 30 May 2021.

124 Howse (n 9) 217.

${ }^{125}$ Lauren Cole, 'Investor-State Dispute Settlement Reform: The Multilateral Investment Court Was Never The Answer' <http://www.mjilonline.org/investor-state-dispute-settlement-reform-the-multilateralinvestment-court-was-never-the-answer/> accessed 30 May 2021.

126 Pauwelyn (n 12) 378.

127 ibid 416.
} 
arbitral awards may organically lead to stability and predictability of the awards rather than introducing a formal appellate body.

Introducing the Multilateral Investment Court should go hand in hand with the careful drafting of investment protection provisions in international investment instruments as a structural re-branding is not sufficient to cure the dispute settlement system. Otherwise, it may share the fate of the Appellate Body.

\section{Concluding remarks}

ISDS mechanism was severely criticised in recent years. The complaints mostly concerned the asymmetric protection regime under IIAs, the unpredictability of arbitral awards and alleged lack of independence and impartiality of the appointed arbitrators. However, despite the shortcomings of the current system, it has been argued that instead of trying to amend it and introduce the Multilateral Investment Court, States "can, should, and will negotiate new IIAs". ${ }^{128}$ Saulino and Kallmer argue that ISDS mechanism is not faulty as such. The issue rather lies with the way the investment treaties were concluded in the past - in order to attract more investments, States were willing to provide a greater protection regime. Therefore, merely replacing a dispute settlement mechanism may turn out to be a futile attempt to improve the system. The proposed replacement of "arbitrators with judges does not by any means guarantee a transformation of the regime". ${ }^{129}$

As far as current negotiations are concerned, there is a division amongst the members of the UNCITRAL Commission and the States do not necessarily share the EU's enthusiasm concerning the establishment of the Multilateral Investment Court. Some countries perceive ISDS system to be best suited for resolution of investment disputes, others are working towards multilateralization, however, there are differences in their approach to such a proposal. ${ }^{130}$. Some argue that a reform of existing IIAs with increased transparency and creation of an appellate mechanism would be sufficient. ${ }^{131}$

There is no doubt that the dispute settlement of investment disputes could benefit from certain tweaks, however, as underlined by legal scholars such an evolutionary change could be better suited for achieving the goals of the reform. The proposals in their current shape seem to be following the same mistakes which ultimately led to the paralysis of the WTO dispute settlement system. Introduction of mechanisms which did not work in trade regime into the investment dispute settlement may render the Multilateral Investment Court an unsuccessful enterprise.

128 Saulino and Kallmer (n 96).

129 Howse (n 9) 210.

130 Hoffman (n 80) 8.

131 Hyoeun Yang, 'The EUs Investment Court System and Prospects for a New Multilateral Investment Dispute Settlement System' (2017) SSRN Electronic Journal. 